\title{
A Reviuw: Sustainable Livestock Development in Indonesia
}

\author{
La Ode Muh. Munadi ${ }^{1}$, Harapin Hafid ${ }^{1}$, Achmad Selamet Aku ${ }^{1}$, Musram Abadi ${ }^{1}$ \\ Postgraduate Agricultural Science Animal Husbandry Halu Oleo University \\ Jl. Mayjend. S. Parman, Kemaraya, Kendari City, South East Sulawesi \\ Postal Code: 93121, Indonesian. \\ Email: lmmunadi@gmail.com
}

(Accepted: 22 Februari 2021; Approved: 18 Maret 2021; Published: 28 Mei 2021)

\begin{abstract}
The population of Indonesia in 2021 is about 273 million people. The increasing population is followed by an increase in food needs, including animal food. The area of land as a base of food production does not increase, even tends to decrease due to conversion, abrasion, and submerged seawater as a result of global warming and climate change, as well as the declining quality of natural resources. Animal protein consumption in Indonesia is very low and is expected to increase sharply as the income of the population continues to increase. Anticipating this, it is necessary to prepare a medium- and long-term farm development strategy in a sustainable manner by utilizing the availability of local resources. Exploring the genetic resources of livestock that are efficient in the use of feed, should also be able to utilize feed materials in the form of crop byproducts and agricultural industries. This policy should be supported by technological innovation and sustainable productivity and livestock production. Can save natural resources while reducing greenhouse gas emissions in order to realize the concept of green economy.
\end{abstract}

Keywords: Animal Food, Sustainable Animal Husbandry, Indonesian.

\section{INTRODUCTION}

Food is a human need so it brings consequences in the provision of sufficient food for the people (Purwaningsih, 2008; Akuba \& Mutsyahidan, 2017; Rahmawati et al., 2012). Food includes three major paradigms, namely food sovereignty (Ichsan et al., 2017), food independence (Hapsari \& Rudiarto, 2017), and resilience in the use of sustainable resources (Hotima, 2018; Koswara \& Syathori, 2017).

In 2021 the world population will reach 8 billion and will be 9 billion, the population of Indonesia in 2021 will reach 273 million people from about 235 million people. This indicates that the food needs of the Indonesian population will increase in line with the increasing population (Ohleky et al., 2018; Sadali, 2018; Umanailo, 2018). While agricultural land does not increase, it tends to decrease due to abrasion or due to rising sea levels. Fertile land continues to be converted to non-agricultural use and to add new land is not easy, as land is degraded and productivity decreases (Wahyuni \& Sukarniati, 2018; Zakiah, 2018). Food availability efforts are faced with natural resource problems, especially land and water which are the bases of food producers, feed, fiber, and renewable energy or food, feed, fibre, dan fuel (Fitriyani et al., 2019; Prayitno, 2020). There is even competition in the use of food and non-agricultural land (Sallatang \& Bahri, 2019; Samantha et al., 2019).

Currently, Indonesia's Human Development Index (HDI) is related to a country's economic policy towards the quality of life of its people, having a relationship between the level of animal protein consumption of life expectancy, quality of life, and income of the people of a country (Aritonang et al., 2020). In 2021, the world's animal protein intake is $23.9 \mathrm{~g} /$ capita/day, 
developed countries $49.8 \mathrm{~g} /$ capita/day, developing countries $17.4 \mathrm{~g} / \mathrm{capita} /$ day, and for Indonesia only $5.4 \mathrm{~g} / \mathrm{capita} /$ day, ranked 158th out of 173 countries or at the 15 th lowest. Indonesia's consumption of livestock products is very low compared to some countries in the world (Table 1). Therefore, the development of farms should be focused on increasing the production and consumption of livestock products as a source of animal protein, longterm sustainable livestock development concept is required by utilizing local resources. This journal discusses the development of sustainable farms in Indonesia through the application of technological innovations in the utilization of local resources.

\section{Demand for Animal Food In Indonesia}

Animal protein needs will continue to increase as the population grows, people's income, nutritional awareness, urbanization, and dietary changes. Urbanization changes the lifestyle and consumption patterns of people living in urban areas, with higher incomes than those living in the countryside (Permatasari et al., 2016; Pranadji \& Suhaeti, 2016). Causing the diversification of food and grain that has decreased, on the contrary the demand for fruits, vegetables, meat, milk, and fish will continue to increase (Daru et al., 2017; Saputra, 2016).

Animal protein consumption in Indonesia averages $5.45 \mathrm{~g} / \mathrm{capita} /$ day, consisting of $2.4 \mathrm{~g}$ of meat and $3.05 \mathrm{~g}$ of milk and eggs. Consumption based on livestock origin products averaged $5.93 \mathrm{~kg}$ of meat, 6.91 $\mathrm{kg}$ of milk, and $6.37 \mathrm{~kg}$ of eggs/capita/year (Ditjen Peternakan 2021). While the contribution of livestock protein intake to the total protein consumption of the community is only $10.1 \%$, the contribution of protein of world livestock origin is $27.9 \%$ and for developing countries $22.9 \%$.

Table 1. Comparison of consumption of livestock products of several countries by 2021 .

\begin{tabular}{|c|c|c|c|c|c|}
\hline \multirow{3}{*}{ Country } & \multirow{2}{*}{\multicolumn{3}{|c|}{$\begin{array}{c}\text { Livestock Product Consumption } \\
\text { (kg/Capita/year) }\end{array}$}} & \multicolumn{2}{|c|}{ Protein } \\
\hline & & & & \multirow{2}{*}{ g/Capita/Day } & \multirow{2}{*}{$\begin{array}{c}\text { Contribution to } \\
\text { Total Protein }\end{array}$} \\
\hline & Egg & Milk & Meat & & \\
\hline Indonesia & 9,5 & 9,6 & 3,9 & 5,3 & 10,2 \\
\hline China & 69,5 & 24,1 & 21,1 & 28,6 & 26,6 \\
\hline Laos & 18,6 & 6,1 & 1,8 & 7,6 & 10,4 \\
\hline Malaysia & 52,3 & 63,7 & 8,7 & 23,6 & 31,4 \\
\hline Myanmar & 24,0 & 31,3 & 4,4 & 12,1 & 17,3 \\
\hline Viet Nam & 35,9 & 11,2 & 3,2 & 13,7 & 17,3 \\
\hline India & 6,1 & 66,2 & 1,7 & 7,7 & 11,8 \\
\hline Pakistan & 13,2 & 147,2 & 2,1 & 21,7 & 37,7 \\
\hline Sri Lanka & 6,1 & 31,9 & 2,1 & 7,1 & 12,4 \\
\hline Brasil & 81,8 & 130,7 & 7,9 & 28,1 & 41,7 \\
\hline Amerika & 127,6 & 247,4 & 12,7 & 68,1 & 52,5 \\
\hline Australia & 118,6 & 234,8 & 6,1 & 71,3 & 57,7 \\
\hline Inggris & 82,9 & 258,8 & 11,2 & 41,2 & 51,6 \\
\hline
\end{tabular}

Source : FAO (2021)

The increasing number of people causes the main food needs such as rice, soybeans, and sugar will be higher, so that land and water utilization will be prioritized for the main food. Thus, it is increasingly difficult for farms to increase production. Productive grazing land 
will be utilized for food crops and farms will turn towards intensive or semi-intensive farms with a system of integration of livestock crops, especially for ruminant livestock. Likely, farms develop in areas near consumers (suburbs) by bringing in feedstuffs through improvements to the transportation system, especially for poultry livestock.

Livestock species are likely to shift. Easy and fast-growing and producing livestock species are the main choice, such as poultry and pigs as well as other livestock that are more efficient and economical. This can be seen in the structure of Indonesian meat production that continues to struggle (Table 2). The percentage of beef production is higher than chicken meat, but continues to decline.

\section{Problems And Opportunities for Livestock Development In Indonesia}

Livestock production requires sufficient land and water resources about $33 \%$ of the land that can be planted food crops are used for animal feed (feedcrops) or overall about $70 \%$ of the world's agricultural land is used for livestock (Martin et al., 2016). Indonesia, which has a landmass of one-third of its territory (two-thirds are oceans), has only 1.9 million $\mathrm{km} 2$ or 190 million ha of land. The area of rice fields is about 8 million ha, plantations 20 million ha, and forestry 140 million ha. Land for farms is not specifically available so farms do not have special areas such as large pasturas for grazing or for animal feed crops. As a result, livestock maintenance became dispersed and developed in an integrated manner with various existing crops. This situation is different from in Brazil where the land for farms reaches 170 million ha with a beef cattle population of 205 million (Abdullah, 2017; Araujo Enciso et al., 2016; Stark et al., 2016; Veiga et al., 2016).

Farm products have a higher virtual water content than crop products, because livestock is a food chain that is higher in level than plants. In producing $1 \mathrm{~kg}$ of boneless beef required $6.5 \mathrm{~kg}$ of grain, $36 \mathrm{~kg}$ of forage, and 155 liters of water to drink, producing such feed ingredients needed 15,340 liters of water. This method of calculation is in producing 1 ton of chicken meat, 1 ton of pork, and 1 ton of beef required virtual water $3,900 \mathrm{~m} 3,4,900$ $\mathrm{m} 3$, and 15,500 $\mathrm{m}^{3}$ (Bieluczyk et al., 2017; Clarisse Maia Lana Nicoli et al., 2017; Gamarra et al., 2017; Josefina, 2017).

Intensive breeding is wasteful in the utilization of natural resources, because to produce $1 \mathrm{~kg}$ of beef requires $20 \mathrm{~kg}$ of feed, for $1 \mathrm{~kg}$ of pork requires $7.3 \mathrm{~kg}$ of feed, and to produce $1 \mathrm{~kg}$ of chicken meat requires $4.5 \mathrm{~kg}$ of feed (Smil 2000). Overall, to produce $1 \mathrm{~kg}$ of animal protein requires about $6 \mathrm{~kg}$ of plant protein. Looking at the data that farms waste natural resources when feed and feed materials are produced specifically by planting animal feed crops and food crops used as feed, so that in addition to requiring a large enough land also competes with food for humans. Intensive breeding systems are designed for high-input and high-output, so livestock are treated as machines to produce to the maximum.

Table 2. Structure of meat production in Indonesia, 1970-2020.

\begin{tabular}{ccccc}
\hline Year & $\begin{array}{c}\text { Beef } \\
(\%)\end{array}$ & $\begin{array}{r}\text { Poultry meat } \\
(\%)\end{array}$ & $\begin{array}{c}\text { Pig meat } \\
(\%)\end{array}$ & $\begin{array}{c}\text { Other meats } \\
(\%)\end{array}$ \\
\hline 1970 & 53,5 & 12,4 & 11,1 & 23,0 \\
1980 & 38,6 & 30,2 & 10,0 & 21,2 \\
1990 & 25,2 & 49,5 & 12,1 & 13,2 \\
2000 & 23,5 & 56,6 & 11,2 & 8,7 \\
2010 & 18,2 & 63,4 & 9,4 & 9,2 \\
2020 & 17,7 & 63,7 & 34,4 & 6,7 \\
\hline
\end{tabular}

Source: Daryanto (2011), and FAO (2021).

Intensive farms are also signaled as a contributor to considerable greenhouse gas 
(GHG) emissions, about 18\% (Kinkela et al., 2017; Moraine et al., 2017). Intensive farms that are said to be quite cheap have not actually taken into account the negative impacts caused (costs to overcome environmental damage, GHG emissions, draining of natural resources).

Although the use of natural resources in producing animal protein is more wasteful than vegetable proteins, various studies show that livestock products are a source of high quality protein. Livestock products are also a source of essential micro-nutrients such as $B$ vitamins and trace element elements such as iron $(\mathrm{Fe})$ and zinc $(\mathrm{Zn})$ which have high bioavailability value (high degree of absorption and utilization), in addition to containing certain essential amino acids. This level of bioavailability is important for mothers and toddlers. Micronutrients are usually difficult to obtain from food of plant origin because bio availibility is low. Food of livestock origin is essential for maternal health and physical and mental development of toddlers (Budiawati \& Natawidjaja, 2020; Delly et al., 2020; Dwiartama et al., 2020; Harvian \& Yuhan, 2020). Malnutrition due to animal protein deficiency is believed to be the cause of mental and physical disorders of toddlers, in addition to being prone to malaria, tuberculosis and HIV/AIDS.

\section{Technology Opportunities and Innovations Farm Development}

Increasing productivity and world food production, technological innovation plays a very large role, which is about $80 \%$, much greater than the role of land expansion which is only $20 \%$ because land resources are already very limited. Efforts to increase productivity and livestock production. Broiler breeding research has now reached its peak in producing broiler strains that can reach maximum body weight with high feed efficiency in a relatively fast time. In 1960, achieving a broiler weight of $1.8 \mathrm{~kg}$ took 84 days with the conversion of feed, 3.25, while through a series of technologies in 2010 produced broiler strains reached the same weight within 34 days with a feed conversion of 1.54.

Laying hens, producing strains that increase egg production by 330 grains/year, much more than the strains of laying hens in the 1960s. Innovations in breeding technology in native chickens such as kub chicken (Hidayat et al., 2011) play a role in efforts to increase productivity and production of domestic chicken meat by utilizing local chicken genetic resources. Similarly, mojosarialabio duck (MA) is able to increase the production of duck eggs (Ketaren dan Prasetyo 2000; Prasetyo et al., 2003).

Productivity of broiler and laying hens can be accelerated through breeding technology (Hunton 1990; McKay, 2008), technological advances there are limits because chickens are more susceptible to disease and require highquality feed generally competes with human foodstuffs. In the long run, there are other problems without efforts to preserve native genetic resources, because breeding chickens can cause genetic defects. Technology development needs to be more careful, not to eliminate natural genetic resources. It does not close the possibility of returning to the utilization of native/local animals that are more disease resistant, responsive to low-quality feed, tend to be environmentally friendly, and relatively easy to maintain.

Cross-section technology to increase beef production in beef has also been widely applied through artificial insemination (IB). Sumatran and Garut composite sheep creation technology can also increase the cutting weight almost twice that of the original sheep in the same maintenance period (Subandriyo et al., 2000; Inounu et al., 2007; Setiadi and Subandriyo 2007; Inounu et al., 2008), but his propagation efforts need to get more attention.

Improving livestock productivity, technology is also needed to produce livestock that are resistant to disease. Breed chickens of high productivity are responsive only with high-quality feed and are susceptible to disease attacks. Native/local livestock with low to moderate productivity can utilize low quality feed ingredients and relatively resistant to disease. Therefore, local livestock can be utilized its superior properties in livestock 
breeding (Badaruddin et al., 2016; Pagala et al., 2018; Ulupi \& Pagala, 2014; Wahyuni et al., 2016).

In addition to breeding technology, feed technology is also needed to overcome the increasing needs of feed ingredients. Various sources of unconventional feed materials available in nature need to be researched in order to be used to meet the needs of animal feed. Abundant palm oil plantation waste has been studied for use as feed and animal feed (Sinurat et al., 2001a, b, c and d; Sinurat 2003; Mathius et al. 2004; Mathius et al. 2007; Mathius 2009). From these studies, it can be concluded that almost all waste of oil palm crops (pelepah and leaves, bunches of empty fruit, palm kernel meal, and solid) can be processed into ready-to-eat feed for ruminants, especially beef cattle (Mathius 2009). Similarly, a mixture of poultry animal feed ingredients can replace/substitute some corn and soybean meal (Sinurat et al., 2001a and c).

Poultry farms generally require feed ingredients that compete with foodstuffs for humans. Therefore, technological innovations such as the use of palm kernel meal (BIS) that can substitute corn up to $10 \%$ in poultry feed (Sinurat et al., $2001 \mathrm{a}, \mathrm{b}, \mathrm{c}$ ) will be very real contribution in saving increasingly limited natural resources. Technological innovations to look for unconventional feed ingredients or derived from agricultural and agro-industrial products need to be continuously developed. Research on the utilization of palm oil plantation industry byproducts as animal feed material has been conducted, especially by countries that have palm oil plantation businesses such as Malaysia and Indonesia (Yeong et al., 1983; Aritonang 1984; Hassan et al., 1991; Hassan \&Ishida 1992; Ishida \&Hassan 1997). In Indonesia, the research began to develop in the 1990s, as shown in Table 3.

Table 4 presents data on planting area, harvest area, and production of various commodities of food crops and plantations whose byproducts can be used as feed materials. The data on the table illustrates the potential for agricultural products as a source of animal feed. Biomass produced from the palm oil industry (assuming 5 million ha has been produced), according to Mathius (2009) reached 68.7 million tons derived from pelepah, leaves, empty bunches, BIS, palm sludge or solid. If only $50 \%$ of the biomass is used for cattle feed, then the number of cows that can be accommodated reaches 13.2 million units of cattle (animal unit/AU). One AU is equivalent to a live weight of $250 \mathrm{~kg}$ and consumption every $1 \mathrm{AU}$ is about $3.5 \%$ of the live weight, so that value is equivalent to 18.9 million adult cows, of which one adult cow is equivalent to $0.7 \mathrm{AU}$ (Mathius 2009). If $75 \%$ of the biomass is used for cattle, it can meet the needs of 27.35 million cows. In other words, the total biomass available from the palm oil industry can meet the needs of 37.8 million cows

Table 3. Technological innovation in the utilization of agricultural byproducts for animal feed in Indonesia.

\begin{tabular}{llll}
\hline \multicolumn{1}{c}{ By-products } & \multicolumn{1}{c}{ Uses } & \multicolumn{1}{c}{ Use } & \multicolumn{1}{c}{ Referensi } \\
\hline $\begin{array}{l}\text { Palm kernel meal (BIS) } \\
\text { BIS, palm oil, } \\
\text { palm oil leaves }\end{array}$ & $\begin{array}{l}\text { Broiler feed } \\
\text { Complete feed of } \\
\text { goats }\end{array}$ & $\begin{array}{l}\text { 5\% from rations } \\
\text { Composition of 29\% } \\
\text { palm leaves, 50\% } \\
\text { BIS, and 20\% }\end{array}$ & $\begin{array}{l}\text { Ketaren } \text { et al., (1999) } \\
\text { Batubara } \text { et al., (2004) }\end{array}$ \\
Palm sludge & $\begin{array}{l}\text { Lamb feed } \\
\text { mixture }\end{array}$ & $\begin{array}{l}\text { Replaces 60\% bran } \\
\text { as concentrate }\end{array}$ & Harfiah (2009) \\
Palm kernel meal (BIS) & $\begin{array}{l}\text { Feed replacement } \\
\text { BIS can be given up } \\
\text { to 58\%, but an } \\
\text { economical 30\% } \\
\text { complional }\end{array}$ & Mathius (2010) \\
All industrial byproducts & $\begin{array}{l}\text { Ready to eat feed } \\
\text { for }\end{array}$ & Mathius et al., (2007)
\end{tabular}




\begin{tabular}{|c|c|c|c|}
\hline $\begin{array}{l}\text { palm oil (the number of } \\
\text { palm oil, } \\
\text { solid fermentation } \\
\text { products and BIS, solid) }\end{array}$ & $\begin{array}{l}\text { bali bunting cows } \\
\text { and } \\
\text { lactation as well as } \\
\text { for fattening }\end{array}$ & $\begin{array}{l}\text { Komposisi } 33 \% \text { cacahan } \\
\text { pelepah, } \\
33 \% \text { produk fermentasi solid, } \\
33 \% \text { solid, }\end{array}$ & $\begin{array}{l}\text { Mathius (2008) } \\
\text { Ashari \& Juarini (2010) }\end{array}$ \\
\hline $\begin{array}{l}\text { Byproducts of sugar } \\
\text { cane crops and sugar } \\
\text { industry }\end{array}$ & $\begin{array}{l}\text { Beef feed } \\
\text { material }\end{array}$ & $\begin{array}{l}\text { Potential feed ingredients } \\
\text { from sugarcane shoots, } \\
\text { leaves } 4.62 ; 1,98\end{array}$ & Zulbadri et al., (1999) \\
\hline $\begin{array}{l}\text { Palm sludge } \\
\text { (fermentation and } \\
\text { without fermentation) }\end{array}$ & $\begin{array}{l}\text { Chicken feed } \\
\text { ingredients } \\
\text { and ducks }\end{array}$ & $\begin{array}{l}\text { Corn or meal } \\
\text { ducks can be given up to } \\
15 \% \text {, broiler chickens and } \\
\text { native chickens up to } 10 \%\end{array}$ & $\begin{array}{l}\text { Sinurat et al., (2001a, } \\
\text { b, c, d) Sinurat (2003) }\end{array}$ \\
\hline $\begin{array}{l}\text { Food crop waste } \\
\text { (rice straw) }\end{array}$ & $\begin{array}{l}\text { Cow feed material } \\
\text { Cut }\end{array}$ & $\begin{array}{l}\text { For the main feed in season } \\
\text { drought, with } \\
\text { fermentation or } \\
\text { preservation }\end{array}$ & $\begin{array}{l}\text { Haryanto et al., (2002) } \\
\text { Haryanto \& Yulistiani } \\
\text { (2009). }\end{array}$ \\
\hline
\end{tabular}

Table 4. Land area, production of food crops and plantation crops whose byproducts are potential as a source of feed.

\begin{tabular}{lcccl}
\hline \multirow{2}{*}{\multicolumn{1}{c}{ Commodities }} & \multicolumn{2}{c}{ Year 2019 } & \multicolumn{2}{c}{ Year 2020 } \\
\cline { 2 - 5 } & Harvest Area & Production & Harvest Area & Production \\
\hline Rice Plants & 13.149 & 67.157 & 13.227 & 70.131 \\
Corn Crops & 4.631 & 23.288 & 4.112 & 17.421 \\
Soybean Plant & 559 & 493 & 691 & 881 \\
Peanut Plant & 760 & 689 & 623 & 660 \\
Green Bean Plant & 406 & 222 & 288 & 287 \\
Cassava Plant & 2.201 & 15.988 & 1.214 & 21.615 \\
Sweet Potato Plant & 177 & 1.984 & 216 & 1.772 \\
Rubber Plantation & 4.414 & 2.644 & 3.371 & 2.832 \\
Oil palm plantations & 6.767 & 16.555 & 8.118 & 17.129 \\
Plantations & 4.788 & 3.182 & 4.687 & 3.256 \\
Coffee Plantation & 2.296 & 577 & 1.333 & 674 \\
Cocoa Plantation & 2.379 & 840 & 1.572 & 784 \\
Sugar cane Plantation & 328 & 3.724 & 521 & 2.921 \\
\hline
\end{tabular}

Source: Ministry Agriculture (2021).

Likewise for rice straw, each harvest can produce about 5 t/ha (Haryanto et al., 2002). With the content of dry material (BK) straw $40-45 \%$, then BK straw about 2-2.5 t/ha/ harvest. Bk straw needs for cows with a weight of $250 \mathrm{~kg}$ ranging from 6-7 kg/day (Haryanto and Yulistiani 2009), so cows weighing 300$350 \mathrm{~kg}$ need about $10 \mathrm{~kg}$ bk straw. If rice is planted 2-3 times a year, then BK straw from 1 ha of rice plants per year can meet the needs of two cows. With an area of rice plants of about 8 million ha, the production of straw can meet the needs of about 16 million cows. Not to mention the byproducts of crops and rubber plantations, coffee, cocoa, and so on.

Technological innovations to safeguard livestock from disease and death are also needed to increase livestock productivity and animal food production. Technology of making and developing ND vaccines can prevent poultry from attacks of deadly tetelo disease. Similarly, the technology of helminthic drugs can increase the productivity of livestock. The same is shown in the prevention of the death of 
calves and pigs through the development of ETEC and VTEC (enterotoxemia E. coli) vaccines using local isolates (Supar 2008). This situation illustrates that technological innovation is needed to overcome the limitations of various conventional feed resources. Therefore, the application of technological innovation must be encouraged to increase animal food production and investment in research and development must be continuously improved.

\section{Future Farm Development Strategies}

The strategy of producing animal food sustainably with increasingly limited natural resources, the right strategy is needed as follows.

\section{Choosing a Livestock Development Site}

Determination of the location of farms should pay attention to various factors, such as access to markets or consumers, proximity to feed sources, land availability, infrastructure, transportation, labor, and the status of animal diseases. The program plan will be further developed in Sumatra because it has a source of feed from plantation follow-up supported by road infrastructure with the construction of the Sunda Strait bridge. Java is estimated to have a large enough livestock business because the transportation of feed materials from Sumatra will be easier.

\section{Sub-optimal Land Use Farm Mining}

Limited land and natural resources cause food crops such as rice, corn, soybeans, and sugar cane, always transferring forests Therefore, developing livestock in an integrated manner with food crops, plantations, and horticulture, farms can be developed on suboptimal land that is still very large and not optimally utilized. East Nusa Tenggara (NTT) and West Nusa Tenggara (NTB) have a large suboptimal land, and the province of Bali is directed as the center of beef cattle farming. The limited availability of infrastructure, transportation, and feed sources is a limiting factor that must be addressed to prepare its operational programs.
Kalimantan diprioritaskan sebagai lumbung energi, dan pengembangan perkebunan sawit. Kalimantan banyak memiliki lahan suboptimal, sehingga peternakan sapi potong dapat dikembangkan dengan memanfaatkan bahan pakan dari limbah sawit dan bahan pakan lokal lainnya. Daerah produsen ternak seperti Nusa Tenggara dan Kalimantan, dapat menyuplai ternak hidup ke daerah konsumen (Jakarta), juga dapat dikembangkan usaha peternakan sektor hilir seperti rumah potong hewan (RPH), sehingga yang diperdagangkan tidak lagi sapi hidup, tetapi daging segar maupun daging semi olahan.

\section{Optimizing LEISA patterns and Zero Waste}

Strategy low external input sustainable agriculture (LEISA) and zero waste with the integration system of livestock-crops is the concept of environmentally friendly sustainable development in improving the efficiency of the use of natural resources and reducing GHG emissions. The fulfillment of animal feed from the follow-up of plantation crops and food crops or agro-industry does not require special land so as to save the use of land and water resources. Planting feed crops and food crops intended for livestock will increase the use of new land and water (Steinfeld et al., 2006; Lundqvist et al., 2008).

Leisa and zero waste patterns are optimized by utilizing the biomass of oil palm, rubber, and coconut plantations as well as byproducts of coffee, cocoa, sugar cane, food crops, horticulture and agricultural industry follow-up products as feed sources. Biomass volume is estimated from the area of harvest or planting area with the production of food crops and plantations. A considerable volume of biomass strongly supports the development of land and water farms. This concept has been widely applied in Indonesia (Guntoro 2011). The LEISA concept is the development of sustainable farms by utilizing local resources efficiently.

\section{Building a Feed Factory Industry}

The development of farms should not only be directed to Nusa Tenggara, Bali, as 
well as Papua and Maluku, but in their operations can be developed in Sumatra, Kalimantan, and Sulawesi if resources are available. The development of oil palm plantations in Sumatra and Kalimantan will be available in large quantities of biomass as feed material. In the center of oil palm plantations can be built animal feed plants from the followup of oil palm plantations (Mathius 2008 and 2009). This program is very appropriate as part of the development of sustainable farms.

Biomass utilization strategy, livestock development does not have to be in the plantation environment, but the biomass can be taken out, both in the form of fresh and processed feed raw materials, even when possible in the form of complete feed on a commercial scale. This strategy is supported by building a feed mill industry around plantations or biomass centers. Feed mills can be a branch of the plantation business.

\section{Building An Integrated Farm}

Integrated beef cattle farming industrial estates can be built in oil palm plantations from upstream to downstream. It can be developed by plantations as one of the business branches. In this case the source of feed still relies on plantation waste that is processed into ready-toeat feed so that it will be obtained cheap feed. In addition to the feed factory, rph was also built. Beef farming is done until cutting to produce meat making it easier to transport and marketing.

\section{Utilization of Genetic Resources Local Cows}

Utilizing the genetic resources of livestock is choosing a commodity that can be developed. Such as balinese cows and PO cows because it has been able to adapt to the environment and local feed sources are available. Other local cows such as madura and aceh cattle can also be developed. Crossing with the nation of exotic cows should only be for meat production, so there is no need to cross until F2 and so on. This strategy will also ensure the sustainability of local livestock genetic resources so that sustainable livestock development will be realized.

\section{Increase Meat Consumption}

The genetic resources of local goats and sheep can be increased production and consumption to the community through promotion and socialization so that perceptions about goat meat as the cause of high blood disease, stroke, and heart disease can be minimized. The pattern of meat consumption in both types of livestock by reducing the fat content and offal needs to be disseminated. The development of composite goats and sheep from research needs to be facilitated by the government in order to be utilized by farmers.

\section{Development of Poultry, Pigs, and Assorted Livestock}

Local chickens and ducks are a genetic resource of local livestock that must continue to be developed. Thus, productivity increases and sustainability is more assured. Disease management should receive special attention so that the declining population can increase again and avoid the threat of infectious disease outbreaks such as AI, tetelo, and poultry cholera. Pigs are suitable to be developed in NTT, Bali, North Sulawesi, Papua, and North Sumatra in accordance with the socio-cultural of the local community, in addition to increasing jobs, income, and nutrition of local people. People's farms should be developed by increasing the scale of business in the form of capital, institutional, and coaching and utilizing infrastructure. Rabbits and quails are developed through the Sustainable Food House Area (KRPL) in improving the nutritional adequacy of animal food in the community.

\section{Availability of Breed Chicken Seedlings}

The availability of breed chicken seedlings should be utilized optimally. Seed production reaches $70 \%$. Considering the low consumption of animal protein in Indonesia, the production of meat and eggs of breed chickens can be increased by increasing the production capacity of DOC (day old chick) seedlings by $30 \%$ of the remaining capacity. This effort must be accompanied by increasing purchasing power or changing non-braid consumption patterns (such as cigarettes and 
pulses) to nutritious food consumption patterns by socializing to lower class communities. The addition of DOC seed production is supported by the production of feed mills that are currently producing only $70 \%$ of the existing capacity. This strategy should be carried out comprehensively because it involves upstream subsystems (seedlings, feed, medicines, and so on), cultivation subsystems (plasma-core, partnerships), and downstream subsystems (cutting, marketing, and so on).

\section{Improving Research and Development}

Feed technology is needed in meeting the needs of feed and feed derived from domestically available resources such as agricultural waste, forestry, and agro-industrial waste. Local livestock breeding technology needs to be continuously developed. The role of technological innovation in improving productivity and livestock production is very important so that research is needed in a targeted manner.

In line with putting Indonesia towards food sovereignty as a spirit, in order to meet the food of the Indonesian population must be built the ability to produce their own food sustainably by utilizing available natural resources. The export of raw materials must be reduced along with the ability to process raw materials by mastering technological innovations. Raw materials of organic waste such as pineapple waste, palm kernel meal, sugar cane shoots, and biopelets, must be stopped and processed themselves into complete feed has added value for domestic interests.

The demand for food from semiprocessed and ready-to-eat livestock will increase, it requires technological innovation of processed livestock products or post-harvest technology. This needs to be anticipated by conducting various researches of post-harvest technology of products of livestock origin.

\section{Fresh Food and Processed Food From Livestock}

The main programs of fresh food development, namely increasing the added value of production, efficiency of distribution and production, as well as strengthening the innovation system. More efficient if the beef produced by NTB and NTT is marketed to the producer area (Jakarta for example) in the form of fresh or semi-olahan meat by cutting and processing it in the producer area (NTT/NTB). Thus in NTT / NTB (producer area) must be built RPH international standards as well as processing and packaging plants.

The development of beef cattle centers in NTT/NTB requires investment, so as to grow employment and the regional economy. The safety of livestock products is more assured, the spread of disease can be reduced, and animal welfare is increased. However, it must be followed by education/socialization to the community in eating fresh or frozen meat. Meanwhile, in the area of consumers who have RPH will indeed lose employment opportunities and try, so it is necessary to find a solution, for example by becoming a distributor of livestock products.

\section{Developing Livestock Research Results}

Breeding livestock that have productivity and adaptation advantages must be developed to accelerate the increase in animal food production. Thus, the researcher's relationship with breeders and users will become close, later more research activities are based on the needs of users and vice versa the results of the study are immediately utilized by users because the livestock of the research results can be directly reproduced by the breeding institutions.

\section{CONCLUSIONS AND SUGGESTIONS}

The fulfillment of animal food needs in a sustainable manner needs to be done:

1. Development of livestock breeding technology innovation, reproductive technology, feed technology and disease control to increase productivity and local livestock production.

2. Breeding livestock from research that has high productivity and adaptability

3. Utilization of feed material sources from agricultural byproducts and agricultural industries.

4. Construction of feed mills made from raw products produced by oil palm plantations. 
5. Development of feed technology innovation to utilize unconventional feed and feed materials.

6. Increased research investment and applicative development to improve the genetic quality of local livestock.

\section{REFERENCES}

Abdullah, M. (2017). Determination Of Forage Productivity, Carrying Capacity And Palatability Of Browse Vegetation In Arid Rangelands Of Cholistan Desert (Pakistan). Applied Ecology And Environmental Research, 15(4), 623637.

Akuba, R. H., \& Mutsyahidan, A. M. A. (2017). Gorontalo Province Food Security and Vulnerability Map of the Year 2015. Jurnal Technopreneur (Jtech), 5(2), 67-83.

Araujo Enciso, S. R., Fellmann, T., Pérez Dominguez, I., \& Santini, F. (2016). Abolishing Biofuel Policies: Possible Impacts On Agricultural Price Levels, Price Variability And Global Food Security. Food Policy, 61, 9-26.

Aritonang, E. A., Margawati, A., \& Dieny, F. F. (2020). Analysis of Food Expenditure, Food Security And Nutrition Intake of Children Under Two Years (Baduta) As Stunting Risk Factors. Journal Of Nutrition College, 9(1), 71-80.

Aritonang, D. (1984). The Effect of Using Palm Kernel Meal in Growing Pig Rations. Dissertation. Graduate Faculty of Bogor Agricultural University.

Ashari \& E. Juarini. (2010). Financial review of the complete concentrate ration of palm oil waste-based beef cattle. pp. 105-115. Proceedings of National Seminar on Animal Husbandry and Veterinary Technology, Bogor, 3-4 August 2010.
Center for Livestock Research and Development, Bogor.

Badaruddin, R., Nafiu, L. O., \& Pagala, M. A. (2016). Genetic Analysis of Tolaki Chickens During Growth. Jurnal Ilmu Dan Teknologi Peternakan Tropis, 2(1), 28-38.

Bieluczyk, W., Pereira, M. G., Guareschi, R. F., Bonetti, J. D. A., Silva, G. N. Da, \& Silva Neto, E. C. Da. (2017). Soil Carbon And Nitrogen Stocks, Light Organic Matter, And Remaining Phosphorus Under A Crop-Livestock Integration System. Semina: Ciências Agrárias, 38(4), 18-25.

Budiawati, Y., \& Natawidjaja, R. S. (2020). Situation And Description of Food Security In Banten Province Based on Fsva Map And Food Security Indicators. Jurnal Agribisnis Terpadu, 13(2), 187-204.

Batubara, L.P., S.P. Ginting, M. Doloksaribu, \& Junjungan. (2004). The effect of the combination of palm kernel meal with palm sludge and molasses supplementation on the growth of cut goats. pp. 402-406. Proceedings of National Seminar on Animal Husbandry and Veterinary Technology, Bogor, 4-5 August 2004. Center for Livestock Research and Development, Bogor.

Clarisse Maia Lana Nicoli, Abílio Rodrigues Pacheco, Cristiane Aparecida Fioravante Reis, \& Fábio Venturoli. (2017). Income Diversification Through A Crop-Livestock-Forest Integration System In The Midwest Brazilian Region. Journal Of Agricultural Science And Technology B, 7(6), 234-239.

Daru, T. P., Juraemi, J., \& Yusuf, R. (2017). Beef Cattle Farming Business Strategy In Post-Coal Mining Land. Jurnal Pertanian Terpadu, 5(1), 85-97.

Delly, D. P., Prasmatiwi, F. E., \& Prayitno, R. T. (2020). Level of Food Security of 
Fishermen's Households In Sukajaya Lempasing Village, Teluk Pandan District, Pesawaran Regency. Jurnal Ilmu Ilmu Agribisnis: Journal Of Agribusiness Science, 7(2), 141-148.

Ditjen Peternakan. (2021). Farm Statistics 2021. Directorate General of Animal Husbandry, Jakarta.

FAO. (2021). The State of Food and Agriculture. Livestock in the balance. FAO, Rome.

Dwiartama, A., Tresnadi, C., Furqon, A., \& Pratama, M. F. (2020). Building Food Security Through The Local Food Movement: Case Studies In Bandung. Jurnal Sosioteknologi, 19(1), 92-111.

Fitriyani, F., Adyatma, S., \& Kumalawati, R. (2019). Analysis of Food Security Level in Banjar Regency, South Kalimantan Province. JPG (Jurnal Pendidikan Geografi), 5(3), 13-19.

Gamarra, É. L., Morais, M. D. G., Almeida, R. G. De, Paludetto, N. A., Pereira, M., \& Oliveira, C. C. De. (2017). Beef Cattle Production In Established Integrated Systems. Semina: Ciências Agrárias, 38(5), 3241.

Guntoro, S. (2011). It's Time to Implement Techno-Ecological Agriculture. A future agricultural model for addressing climate change. PT Agromedia Pustaka, Bogor. pp. 174

Hassan, O.A., S. Ismael, A.R. Mohd Jaafar, D. Nakanishi, N. Dahlan, \& S.H. Ong. (1991). Experience and challenges in processing, treatments, storage and feeding of oil palm trunks based diets for beef production. pp. 231-245. Proc. Seminar on Oil Palm Trunks and Others Palmwood Utilization, MSAP. Kuala Lumpur, Malaysia.

Hassan, O.A. \& M. Ishida. 1992. Status of utilization of selected fibrous crop residues and animal performance with special emphasis on processing of oil palm frond (OPF) for ruminant feed in Malaysia. Trop. Agric. Res. Series. 24: 135-143.

Hapsari, N. I., \& Rudiarto, I. (2017). Factors Influencing Food Insecurity and Security And Its Policy Implications In Rembang Regency. Jurnal Wilayah Dan Lingkungan, 5(2), 125-140.

Harfiah. (2009). Dried palm oil sludge as a substitute for rice bran in ruminant rations. pp. 463-467. Proceedings of National Seminar on Animal Husbandry and Veterinary Technology, Bogor, 1314 August 2009. Center for Livestock Research and Development, Bogor.

Harvian, K. A., \& Yuhan, R. J. (2020). Kajian Perubahan Iklim Terhadap Ketahanan Pangan. Seminar Nasional Official Statistics, 2(1), 1052-1061.

Hidayat, C., S. Iskandar, \& T. Sartika. (2011). Performance response of Balitnak's superior kampung chicken eggs (KUB) to the treatment of ration proteins during growth. JITV 16(2): 83-89.

Hotima, S. H. (2018). Performance and Prospects of Rice Commodity Food Security In Jember Regency. Majalah Ilmiah Dian Ilmu, 11(1), 21-18.

Hunton, P. (1990). Industrial breeding and selection. pp. 985-1028. In R.D. Crawford (Ed.). Poultry Breeding and Genetics. Elsevier, Amsterdam.

Ichsan, M., Sofyan, S., \& Zakiah, Z. (2017). The Role of Peasant Women towards Food Security of Poor Households in Simpang Tiga Subdistrict, Aceh Besar. Jurnal Ilmiah Mahasiswa Pertanian, 2(2), 214-224.

Inounu, I. Subandriyo, E. Handiwirawan, \& L. O. Nafiu. (2007). Estimating the value of breeding and genetic trends of garut sheep and their crosses. JITV 12(3): 225-241. 
Inounu, I., D. Mauluddin, \& Subandriyo. (2008). Characteristics of the growth of garut sheep and its crosses. JITV 13(1): 13-22.

Ishida, M. \& O.A. Hassan. (1997). Utilization of oil palm frond as cattle feed. JARQ 31: 41-47.

Josefina, C. O. (2017). Effect Of Cover Crops On Physico-Chemical Attributes Of Soil In A Short-Term Experiment In The Southwestern Amazon Region. International Journal of Psychology And Counselling, 9(7), 42-50.

Ketaren, P.P. dan L.H. Prasetyo. 2000. Productivity of MA cross ducks in Ciawi and Cirebon. pp. 198-205. Proceedings of The National Seminar on Animal Husbandry and Veterinary Technology, Bogor, 18-19 September 2010. Center for Livestock Research and Development, Bogor.

Kinkela, P. M., Mutiaka, B. K., Dogot, T., Dochain, D., Rollin, X., Mvubu, R. N., Kinkela, C., Mafwila, J., \& Bindelle, J. (2017). Diversity Of Farming Systems Integrating fish Pond Aquaculture In The Province Of Kinshasa In The Democratic Republic of The Congo. Journal of Agriculture And Rural Development In The Tropics And Subtropics, 118(1), 149-160.

Koswara, A., \& Syathori, A. D. (2017). Factors Related to Food Security of Farmers' Households In Malang. AGRIEKSTENSIA : Jurnal Penelitian Terapan Bidang Pertanian, 16(2), 293302.

Lundqvist, J., C. De Fraiture, \& D. Molden. (2008). Saving Water: From field to fork-Curbing losses and wastage in the food chain. SIWI Policy Brief. SIWI.

McKay, J.C. (2008). The genetics of modern commercial poultry. In Proceedings of the 23rd World's Poultry Congress, Brisbane, Australia, 30 June to 4 July
2008. World's Poultry Science Association, Beekbergen, the Netherland.

Martin, G., Moraine, M., Ryschawy, J., Magne, M.A., Asai, M., Sarthou, J. P., Duru, M., \& Therond, O. (2016). CropLivestock Integration Beyond The Farm Level: A Review. Agronomy For Sustainable Development, 36(3), 53.

Mathius, IW., D. Sitompul, B.P. Manurung, \& Azmi. (2004). Byproducts of plants and processing of palm fruit as a complete feed base for cows. pp. 120-129. Proceedings of the National Workshop on Palm-Cow Integration System. Bengkulu, 9-10 September 2003. Agricultural R\&amp;D Agency, Jakarta.

Mathius, IW., A.P. Sinurat, D.P. Tresnawati, \& B.P. Manurung. (2007). A study of ready-to-eat feed based on palm oil industry byproducts for bunting cows. pp. 51-59. Proceedings of The National Seminar on Animal Husbandry and Veterinary Technology, Bogor, 21-22 August 2007. Center for Livestock Research and Development, Bogor.

Mathius, IW. (2008). Feed-based palm oil industry byproducts for lactation and child weaning bali cows. pp. 173-181. Proceedings of National Seminar on Animal Husbandry and Veterinary Technology, Bogor, 11-12 November 2008. Center for Livestock Research and Development, Bogor.

Mathius, IW. (2009). Palm oil industry byproducts and enrichment technology as integrated cow feed ingredients. pp. 65-109. In A.M. Fagi, Subandriyo, and IW. Rusastra (Eds). Plant Livestock Integration System; Rice-Sawit- Cocoa. Center for Livestock Research and Development, Bogor.

Mathius, IW. (2010). Optimization of the utilization of palm kernel meal for cows fed on the basis of natural grass. pp. 161-169. Proceedings of National 
Seminar on Animal Husbandry and Veterinary Technology, Bogor, 3-4 August 2010. Center for Livestock Research and Development, Bogor.

Moraine, M., Duru, M., \& Therond, O. (2017). A Social-Ecological Framework For Analyzing And Designing Integrated Crop-Livestock Systems From Farm To Territory Levels. Renewable Agriculture And Food Systems, 32(1), 43-56.

Ohleky, M. P., Pattiselanno, A. E., \& Kaplale, R. (2018). Namlai Kerne: Local Wisdom and Food Security Of Werwaru Village, Moa District, Southwest Maluku Regency. Agrilan: Jurnal Agribisnis Kepulauan, 5(2), 114-131.

Pagala, M. A., Aku, A. S., Badaruddin, R., \& Has, H. (2018). Characteristics of Phenotypes And Genotypes Gen GH (Growth Hormon) On Chicken Tolaki. Jurnal Ilmu Dan Teknologi Peternakan Tropis, 5(3), 1-4.

Permatasari, N., Priyarsono, D. S., \& Rifin, A. (2016). Agricultural-Based Regional Economic Development Planning in order to Reduce Poverty in West Kalimantan. Jurnal Agribisnis Indonesia (Journal Of Indonesian Agribusiness), 4(1), 27-42.

Pranadji, T., \& Suhaeti, R. N. (2016). The Future of Rural Agriculture In Bali In The Perspective of Regional Development Planning. Analisis Kebijakan Pertanian, 10(3), 225-238.

Prasetyo, L.H., B. Brahmantiyo, dan B. Wibowo. (2003). P roduksi egg cross mojosari duck and alabio as the seed of the superior commercial duck laying. pp. 360-364. Proceedings of The National Seminar on Animal Husbandry and Veterinary Technology, Bogor, 2930 September 2003. Center for Livestock Research and Development, Bogor.
Prayitno, G. P. (2020). Food Security District/ City of West Java Province. Agribusiness Journal, 14(1), 12-19.

Purwaningsih, Y. (2008). Food Security: Situations, Problems, Policies, And Community Empowerment. Jurnal Ekonomi Pembangunan: Kajian Masalah Ekonomi Dan Pembangunan, 9(1), 1-27.

Rahmawati, Y., Nurani, A. S., Sukandar, D., \& Khomsan, A. (2012). Food Independence Sources Carbohydrates And Proteins To Realize Family Food Security. INVOTEC, 8(2), 30-37.

Sadali, M. I. (2018). Sustainable Food Security in Sukoharjo Regency. Jurnal Geografi, 10(1), 86-97.

Sallatang, A. A., \& Bahri, S. (2019). P Food Security Institution in Pare-Pare City. Pangadereng: Jurnal Hasil Penelitian Ilmu Sosial Dan Humaniora, 5(1), 162 174.

Samantha, Y., Menganti, N. S., \& Amaliah, L. (2019). Study of Household Food Security of Tea Growers Farmers. JURNAL AGRIBISAINS, 4(2), 22-29.

Saputra, J. I. (2016). Analysis of Potential Development of Beef Cattle Farms in Pesawaran Regency. Jurnal Ilmiah Peternakan Terpadu, 4(2), 115-123.

Setiadi, B. \& Subandriyo. (2007). Productivity of composite sheep sumatra and barbados cross in field conditions. JITV 12(4): 306-310

Sinurat, A.P., T. Purwadaria, P. P. Ketaren, D. Zainuddin, \& I. P. Kompiang. (2001a). Utilization of palm sludge for poultry rations: Dry palm oil and fermented products as broiler chicken feed ingredients. JITV 5(2): 107-112.

Sinurat, A.P., I.A.K. Bintang, T. Purwadaria, \& T. Pasaribu. (2001b). Utilization of palm sludge for poultry rations: Dry 
palm sludge and fermented products as feed for growing male ducks. JITV 6(1): 28-33.

Sinurat, A.P., T. Purwadaria, T. Pasaribu, J. Darma, I.A.K. Bintang, \& M.H. Togatorop. (2001c). Utilization of palm sludge for poultry rations: Use of fermented palm sludge products before and after drying in broiler rations. JITV 6(2): 107-112.

Sinurat, A.P., T. Purwadaria, T. Pasaribu, J. Darma, I.A.K. Bintang, dan M.H. Togatorop. (2001d). Utilization of palm sludge for poultry rations: Use of fermented palm sludge products before and after drying in the ration of growing native chickens. JITV 6(4): 274-280.

Sinurat, A.P. (2003). Utilization of palm sludge for poultry feed materials. Wartazoa 13(2): 39-47.

Stark, F., Fanchone, A., Semjen, I., Moulin, C.H., \& Archimède, H. (2016). CropLivestock Integration, From Single Practice To Global Functioning In The Tropics: Case Studies In Guadeloupe. European Journal Of Agronomy, 80, 920.

Steinfeld, H., P. Gerber, T. Wessenaar, V. Castel, M. Rosales, \& C. de Haan. (2006). Livestock's Long Shadow: Environmental issues and option. FAO, Rome.

Subandriyo, B. Setiadi, E. Handiwiryawan, \& A. Suparyanto. (2000). Performance of composite sheep from crosses between local sumatran sheep and hair sheep in the condition of the. JITV 5(2): 73-83.

Ulupi, N., \& Pagala, M. A. (2014). Identify Diversity Gen Toll-Like Receptor-4 On Chicken Tolaki, Commercial Laying Hens And Broiler Chickens. Jurnal Ilmu Dan Teknologi Peternakan Tropis, 1(1), 23-31.
Security and Diversification of Community Consumption (Study on Waimangit Village Community in Buru Regency). SOCA: Jurnal Sosial Ekonomi Pertanian, 12(1), 63-74.

Veiga, M. D., Pandolfo, C. M., Junior, A. A. B., \& Durigon, L. (2016). Effects On Soil And Crop Properties Of Forms Of Sowing, Deferral Intervals And Fertilisation Of The Annual Winter Forage In A Crop-Livestock Integration System. Journal of Agricultural Science, 8(5), 15-22.

Wahyuni, V., Nafiu, L. O., \& Pagala, M. A. (2016). Characteristics phenotype Qualitative And Quantitative Properties of Goat Nuts In West Muna District. Jurnal Ilmu Dan Teknologi Peternakan Tropis, 3(1), 21-30.

Wahyuni, W., \& Sukarniati, L. (2018). Analysis of Food Security of Poor Households. Jurnal Analisis Bisnis Ekonomi, 16(1), 53-62.

Yeong, S.W., T.K. Mukherjee, M. Faizah, \& M.D. Azizah. (1983). Effect of palm oil by-product-based diets on reproductive performance of layers including residual effect on offspring. Phil. J. Vet. Anim. Sci. 9(14): 93-100.

Zakiah, Nfn. (2018). Food Security And Poverty In Aceh Province. Analisis Kebijakan Pertanian, 14(2), 113-124.

Zulbadri, M., T. Sugiarti, N. Hidayati, \& A.M. Karto. (1999). Opportunities for the utilization of sugar cane waste for fattening beef cattle in dry land. Wartazoa 8(2): 33-37.

Umanailo, M. C. B. (2018). Local Food 